\title{
Characterisation and manipulation of docetaxel resistant prostate cancer cell lines
}

\author{
Amanda J O'Neill ${ }^{1 *}{ }^{*}$, Maria Prencipe $^{1 \dagger}$, Catherine Dowling ${ }^{1 \dagger}$, Yue Fan ${ }^{1}$, Laoighse Mulrane $^{2}$, William M Gallagher ${ }^{2}$, \\ Darran O'Connor ${ }^{2}$, Robert O'Connor ${ }^{3}$, Aoife Devery ${ }^{3}$, Claire Corcoran ${ }^{4}$, Sweta Rani ${ }^{4}$, Lorraine O'Driscoll ${ }^{4}$, \\ John M Fitzpatrick' and R William G Watson'
}

\begin{abstract}
Background: There is no effective treatment strategy for advanced castration-resistant prostate cancer. Although Docetaxel $\left(\right.$ Taxotere $^{\circledR}$ ) represents the most active chemotherapeutic agent it only gives a modest survival advantage with most patients eventually progressing because of inherent or acquired drug resistance. The aims of this study were to further investigate the mechanisms of resistance to Docetaxel. Three Docetaxel resistant sublines were generated and confirmed to be resistant to the apoptotic and anti-proliferative effects of increasing concentrations of Docetaxel.

Results: The resistant DU-145 R and 22RV1 R had expression of P-glycoprotein and its inhibition with Elacridar partially and totally reversed the resistant phenotype in the two cell lines respectively, which was not seen in the PC-3 resistant sublines. Resistance was also not mediated in the PC-3 cells by cellular senescence or autophagy but multiple changes in pro- and anti-apoptotic genes and proteins were demonstrated. Even though there were lower basal levels of NF- $\kappa$ B activity in the PC-3 D12 cells compared to the Parental PC-3, docetaxel induced higher NF- $\kappa$ B activity and $I \kappa B$ phosphorylation at 3 and 6 hours with only minor changes in the DU-145 cells. Inhibition of NF- $\kappa$ B with the BAY 11-7082 inhibitor reversed the resistance to Docetaxel.
\end{abstract}

Conclusion: This study confirms that multiple mechanisms contribute to Docetaxel resistance and the central transcription factor NF- $\kappa$ B plays an immensely important role in determining docetaxel-resistance which may represent an appropriate therapeutic target.

Keywords: Docetaxel, Prostate, NF- $\kappa$ ?k?B, Apoptosis, Viability

\section{Background}

Unfortunately there is no effective treatment strategy for advanced castration-resistant prostate cancer [1,2]. Although Docetaxel (Taxotere ${ }^{\mathbb{B}}$ ) currently represents the most active chemotherapeutic agent it only gives a modest survival advantage with most patients eventually progressing because of inherent or acquired drug resistance. A number of mechanisms have been proposed to contribute to this resistance. Firstly, the majority of prostate tumours are slow growing even in metastatic disease and thus are unlikely to respond to drugs that

\footnotetext{
* Correspondence: amanda.oneill@ucd.ie

+ Contributed equally

${ }^{1}$ UCD School of Medicine and Medical Science, UCD Conway Institute of Biomolecular and Biomedical Research, University College Dublin, Dublin, Ireland

Full list of author information is available at the end of the article
}

are S phase-dependent [3]. Secondly, failure of chemotherapy may be caused by reduced intracellular concentrations of a drug through either increased efflux or decreased intake secondary to alterations in drug transporters, particularly P-glycoprotein (P-gp). Multidrug resistance (MDR) mechanisms including increased expression of the P-gp or increased cellular metabolism of drug detoxifying proteins, such as glutathione-Stransferase, have been shown to protect the cancer cells against cytotoxic drugs [4]. Thirdly, alterations in $\beta$ tublin isotypes with different kinetics of microtubule formation have been shown to contribute to resistance. With an increase in isotypes III and IV correlating with Docetaxel resistance in vitro [5]. Fourthly, mutations in tumour suppressor proteins, such as loss of PTEN which is a common event occurring in about $60 \%$ of

\section{Biomed Central}


prostate cancer patients results in the activation of the phosphatidylinositol 3'-kinase (PI3K) signal transduction cascade resulting in increased cellular proliferation and survival mediated by AKT [6]. Finally, as the prostate cancer phenotype progresses there is the expression of survival factors that inhibits the apoptotic cell death pathway [7], mediated in part by the activation of AKT and other survival signalling pathways. Studies by our group and others have identified elevated protein levels of Bcl-2 [7], Inhibitors of Apoptosis proteins (cIAP-1, cIAP-2, XIAP and Survivin) [8], Clusterin and Heat Shock Proteins [9], as important anti-apoptotic proteins in the development of resistance to a number of apoptotic triggers. However the identification and manipulation of these multiple mechanisms represents a significant challenge as targeting individual proteins has little clinical impact. This was demonstrated in a recent phase II clinical trial with oblimersen sodium, a Bcl-2 antisense oligonucleotide and Docetaxel which did not achieve its primary endpoint of reducing PSA and was associated with increased toxicity [10]. However strategies to block multiple Bcl-2 family members are under way with AT101, a small molecular inhibitor of Bcl-2, Bcl-xl, Bcl-w and Mcl-1 (clinicaltrials.gov ID: NCT00571675).

Another approach to block multiple downstream genes is to inhibit central transcription factors. There is increasing evidence that inflammation drives the development and progression of prostate cancer [11]. Nuclear factor kappa B $(\mathrm{NF}-\kappa \mathrm{B})$ is a central transcription factors activated by inflammation and other cells stresses including paclitaxel [12]. Inhibition of NF- $\kappa \mathrm{B}$ with CAPE increases caspase dependent cell death in PC-3 cells mediated via a reduction in IAP expression [12]. Indirect inhibition of NF- $\kappa \mathrm{B}$ with an IKK complex inhibitor enhances Docetaxel induced apoptosis in PC-3 and DU-145 cells [13].

This study was undertaken to further investigate the mechanisms of resistance to Docetaxel. A number of Docetaxel resistant sub-lines were generated in the androgen-independent (PC-3, DU-145) and sensitive (22RV1) cell lines. Resistance in the 22RV1 R cells was explained via over expression of P-gp which could be reversed by its inhibition. DU-145 cells have lower levels of P-gp and the resistance was partially blocked by Elacridar. PC-3 cells had no detectable levels of P-gp and Elacridar had no effect on resistance to Docetaxel. Resistance was also not mediated by cellular senescence or autophagy in the PC-3 cells, but multiple changes in pro- and anti-apoptotic genes and proteins were demonstrated. Even though there were lower basal levels of NF- $\kappa \mathrm{B}$ activity in the PC-3 D12 cells compared to the Parental PC-3, docetaxel induced higher levels of NF- $\kappa \mathrm{B}$ activity and $\mathrm{I} \kappa \mathrm{B}$ phosphorylation with only minor changes in the DU-145 cells. Inhibition of NF- $\kappa$ B with the BAY 11-7082 inhibitor reversed the resistance to Docetaxel.

\section{Materials and methods}

\section{Cell culture and resistant cell line development}

The human prostate cancer cell lines PC-3, DU-145 and 22RV1 were purchased from the American Type Culture Collection (ATCC) and maintained in RPMI-1640 medium supplemented with 10\% Fetal Bovine Serum (FBS), $50 \mathrm{U} / \mathrm{ml}$ penicillin $/ 50 \mu \mathrm{g} / \mathrm{ml}$ streptomycin and $2 \mathrm{mM} \mathrm{L}-$ glutamine (Invitrogen).

PC-3 resistant sub-lines were generated by initially treating with Docetaxel (Sigma) at $4 \mathrm{nM}$ and $8 \mathrm{nM}$ (suspended in dimethyl sulfoxide (DMSO) (Fluke)) in 75 $\mathrm{cm}^{2}$ flasks for 48 hours. After treatment, the surviving cells were re-seeded into new flasks and allowed to recover for 2-3 weeks. After 5 (at $8 \mathrm{nM}$ ) and 7 (at 4 $\mathrm{nM})$ treatments, the dose of docetaxel was increased from $4 \mathrm{nM}$ and $8 \mathrm{nM}$ to $8 \mathrm{nM}$ and $12 \mathrm{nM}$ respectively. The cells underwent a total of 18 treatment cycles at 8 $\mathrm{nM}$ and 12 treatment cycles at $12 \mathrm{nM}$, (cell passage numbers 21-55). Following each treatment they were allowed to fully recover before assessing their resistance to docetaxel and any experimental work. As the passage number of these treated cells increased over time, a subset of PC-3 cells were aged alongside these cells as an appropriate control to ensure that the effects seen were due to resistance rather than due to an ageing effect of the PC-3 cells (PC-3 Ag). In all subsequent experiments, the resistant cells are referred to as PC-3 D8 and PC-3 D12 (reflecting the final treatment doses), and the ageing control cells are referred to as P-C3 Ag. Batches of cells were frozen down and all experiments were carried out on similar passages.

Docetaxel resistant cell lines (DU-145 R; 22RV1 R) were developed over a period of 6 months by stepwise increased concentrations of docetaxel. Cells were continuously maintained in docetaxel, with treatments beginning at the initial $\mathrm{IC}_{50}$ of the respective parent cell lines. Media containing docetaxel was changed every 2-3 days. As cells displayed resistance to treatments of docetaxel the concentration was subsequently increased with final treatment doses of $100 \mathrm{nM}$. Resistance was judged based on decreased cell death and increased proliferation of cells. Age-matched parent cells (DU-145 Ag; 22RV1 Ag) which did not receive treatment were also maintained in culture. Batches of cells were frozen down and all experiments were carried out on similar passages.

\section{Quantification of apoptosis and viability}

Apoptotic events were described as a percentage of total events with hypodiploid DNA assessed by propidium iodide incorporation as previously described [14]. 
Cells were harvested by trypsinisation, permeabilised with a hypotonic fluorochrome solution $(50 \mathrm{mg} / \mathrm{ml} \mathrm{PI}$, 3.4 $\mathrm{mM}$ sodium citrate, $1 \mathrm{mM}$ Tris, $0.1 \mathrm{mM}$ EDTA, and $0.1 \%$ Triton $\mathrm{X}-100$ ) and incubated on ice for 10 minutes prior to analysis. Samples were run on a Beckman-Coulter FC-500 Cytometer. Ten thousand events were gated on PI intensity and analysed using Mplus software.

\section{NF- $\kappa B$ Inhibitor}

Cells (100,000 cells/well) were pre-treated with the NF$\kappa \mathrm{B}$ inhibitor, BAY 11-7082 (Merck), (5 $\mu \mathrm{M})$ for 24 hours after which they were treated with docetaxel $(20$ $\mathrm{nM}$ ) for a further 48 hours before been assessed for apoptosis as previously described above.

\section{P-glycoprotein Inhibitor}

Cells $(100,000$ cells/well) were pre-treated with the Pglycoprotein inhibitor, Elacridar (DCU), (0.25 \& $0.5 \mu \mathrm{M})$ for 24 hours after which they were treated with docetaxel $(20 \mathrm{nM})$ for a further 48 hours before been assessed for apoptosis as previously described above.

\section{3-(4,5)-dimethylthiazol-2-yl-2,5-diphenyltetrazolium bromide (MTT) assay cell viability assay}

Cell viability was assessed by MTT cell staining as previously described [15]. Ten thousand cells/well were cultured in a 96-well plate. Twenty-four hours later, cells were treated with several concentrations of Docetaxel (10 nM, $20 \mathrm{nM}, 50 \mathrm{nM}$ and $100 \mathrm{nM}$ ) for 24, 48 and 72 hours. MTT (50 $\mu \mathrm{l}$ of a $5 \mathrm{mg} / \mathrm{ml}$ in PBS; Sigma-Aldrich) was added to each well and the cells were incubated in a $\mathrm{CO}_{2}$ incubator at $37^{\circ} \mathrm{C}$ for 5 hours. Following media removal, the MTT-formazan formed by metabolically viable cells was dissolved in $200 \mu \mathrm{l}$ of DMSO (SigmaAldrich) and the absorbance was measured in a plate reader at $550 \mathrm{~nm}$.

\section{Senescence-associated-ß-galactosidase activity}

Senescence was assessed by staining cells for $\beta$-galactosidase expression as previously described [16]. Briefly, 150,000 cells were seeded in 6 well/plates, 24 hours later cells were treated with several concentrations of Docetaxel for specific times as determined in the experimental design. The cells were then washed twice with PBS, fixed with $2 \%$ formaldehyde (Sigma) and $0.2 \%$ glutaraldehyde (Sigma-Aldrich) in water for 10 minutes and washed again in $2 \times$ PBS washes. Cells were stained with X-gal staining solution $(1 \mathrm{mg} / \mathrm{ml} \mathrm{X}$-gal, $40 \mathrm{mmol} / \mathrm{l}$ citric acid/sodium phosphate $\mathrm{pH} 6,5 \mathrm{mmol} / \mathrm{l}$ potassium ferrocyanide, $150 \mathrm{mmol} / \mathrm{l} \mathrm{NaCl}, 2 \mathrm{mmol} / \mathrm{l} \mathrm{MgCl}_{2}$ ) for 24 hours in a $\mathrm{CO}_{2}$ incubator at $37^{\circ} \mathrm{C}$ and then rinsed in 2 $\times$ washes of PBS and counted using a phase contrast microscope (Olympus CK2). Senescent cells were expressed as a percentage of the total number of cells counted (300 cells/well).
RNA isolation, CDNA synthesis and Real-time RT-PCR analysis using TaqMan Low Density Arrays

Total RNA was extracted using Trizol reagent (Invitrogen, Paisley, UK) using standard procedures as previously described [17]. The RNA was used to generate cDNA as previously described [17]. PCR amplification of cDNA template was performed in a thermal cycler (Perkin Elmer 7700).

Pre-designed TaqMan probe and primer sets for target genes were chosen from an on-line catalogue (Applied Biosystems). Once selected, the sets were factory-loaded into the 384 wells of TaqMan Low Density Arrays (LDAs). The array format was customized on-line with one replicate per target gene. Expression levels of target genes were normalised to $18 \mathrm{~S}$ rRNA (Additional file 1 lists the 95 genes chosen for inclusion, and their function). Samples were analyzed using the $7900 \mathrm{HT}$ system with a TaqMan LDA Upgrade (Applied Biosystems), according to the manufacturer's instructions. In short, single-stranded cDNA (to final concentration of $100 \mathrm{ng}$ as calculated from starting RNA) was combined with water and TaqMan Universal PCR Master Mix, following by loading $100 \mu \mathrm{l}$ of each sample per port. Thermal cycling conditions were as follows: $50^{\circ} \mathrm{C}$ for $2 \mathrm{~min}, 94^{\circ} \mathrm{C}$ for $10 \mathrm{~min}, 97^{\circ} \mathrm{C}$ for $30 \mathrm{~s}$, and $59.7^{\circ} \mathrm{C}$ for $1 \mathrm{~min}$. Gene expression values were calculated based on the $\Delta \Delta C \mathrm{t}$ method, where one sample was designated the calibrator, through which all other samples were analysed. Briefly, $\Delta C$ t represents the threshold cycle $(C \mathrm{t})$ of the target minus that of $18 \mathrm{~S}$ rRNA and $\Delta \Delta C$ t represents the $\Delta C \mathrm{t}$ of each target minus that of the calibrator. Relative quantities were determined using the equation $2^{-\Delta \Delta C t}$. For the calibrator sample (i.e. normal LCM tissue), the equation is relative quantity $=2^{-0}$, which is 1 ; therefore, every other sample is expressed relative to this [18].

\section{Total cellular protein isolation and western blotting}

Whole cell lysates were extracted from treated cells grown to $90 \%$ confluence on T75 flasks and 6-well plates. Cells were washed in cold PBS (1100 rpm, $1 \mathrm{~min}$, $4^{\circ} \mathrm{C}$ in a microcentrifuge) and resuspended in NP-40, Tris $10 \mathrm{mM}$ pH 8.0, $60 \mathrm{mM} \mathrm{KCl,} 1 \mathrm{mM}$ EDTA pH 8.0, $1.0 \mathrm{mM}$ DTT, $10 \mu \mathrm{l} / \mathrm{ml}$ Protease Inhibitor Cocktail (Sigma P8340)/1 ml of lysis buffer and $10 \mathrm{mM}$ PMSF. Samples were then placed on ice for $10 \mathrm{mins}$ and the cell lysate collected after centrifugation (13000 rpm 5 mins at $4^{\circ} \mathrm{C}$ ). Phosphorylated proteins were isolated using the same protocol above with the addition of 10 $\mu \mathrm{l}$ Phosphatase Inhibitor Cocktail (Sigma P2850)/1 ml of lysis buffer [18].

Total cellular protein was determined by means of the Bradford Assay Protein Detection Kit (Bio-Rad). Equal amounts of protein $(50 \mu \mathrm{g})$ were subjected to SDS polyacrylamide gel electrophoresis on $8-12 \%$ gels before 
being trans-blotted onto Immobilin P (Millipore) membranes as previously described [14]. Western blotting was performed using antibodies to Bax (1/1000, Upstate Biotechnology), Bcl-xL (1/1000), Bcl-2 (1/500, BD Biosciences), Bid (1/1000, Biosource), Clusterin (1/1000), Id1 (1/200, Santa Cruz), LC3 (1/1000) P-gp antibody (Mdr-1 D11, 1/200, Santa Cruz), HSP 90 (1/500, StressMarq Biosciences Inc.) and $\beta$-Actin (1/5000, Sigma), followed by incubation with the appropriate horseradish peroxidase-conjugated secondary antibodies (Cell Signaling). Autophagy was assessed by western blotting, using an antibody against the autophagy marker LC3 (1/1000, Sigma-Aldrich). As a positive control for the induction of autophagy, cells were starved for 2 hours in Earl's balanced salt solution (EBSS). Bafilomycin A1 (20 nM, Sigma) was used as an inhibitor of autophagy. Signals were detected using ECL ${ }^{\mathrm{TM}}$ (Pierce).

\section{Assessment of NK- $\kappa$ B TransAMTM NF- $\kappa$ B Family Transcription Factor Assay Kit}

NF- $\kappa \mathrm{B}$ activity in nuclear extracts in the cell lines was determined using the the TransAM ${ }^{\mathrm{TM}}$ NF- $\kappa \mathrm{B}$ Family Transcription Factor Assay Kit (Active Motif, Belgium). Cells were grown to confluency and nuclear extracts prepared as per the TransAM ${ }^{\mathrm{TM}}$ Assay Kit manual. Briefly, nuclear extracts were suspended in TransAM lysis buffer and nuclear proteins (12 $\mu \mathrm{g}$ total protein) were incubated with immobilized oligonucleotides containing the NF- $\kappa \mathrm{B}$ consensus DNA-binding site (5'GGGACTTTCC-3') for 1 hour at room temperature. After washing, $100 \mu \mathrm{l}$ of one of the diluted NF $\kappa \mathrm{B}$ antibodies (1:1000 antibody in 1X Antibody Binding Buffer) was added to each well being used, including blank wells for 1 hour at room temperature. After 3 washes, $100 \mu \mathrm{l}$ of horseradish-peroxidase-conjugated secondary antibody (1:1000 dilutions) were added to each well for 1 hour at room temperature. The colourimetric substrate was then added after 3 subsequent washes, and the plate was allowed to develop for up to 5 minutes. Following this, the reaction was stopped and absorbance read at $450 \mathrm{~nm}$ on a SpectraMax M2 plate reader (Molecular Devices, CA, USA). Relative activation of the NF- $\kappa \mathrm{B}$ subunits between the three cell lines could then be plotted, with an increase in absorbance being indicative of increased activation.

\section{NF- $\kappa$ B Reporter assay}

NF- $\kappa$ B transcriptional activity was assessed using a plasmid containing the luciferase reporter gene regulated by five copies of an NF- $\kappa$ B responsive element (Promega). A TK-Renilla luciferase plasmid was used as a transfection efficiency control. Plasmids were co-transfected using GeneJuice ${ }^{\circledR}$ Transfection Reagent (Novagen) following the manufacturer's instructions. After 6 hours, cells were treated with or without $50 \mathrm{nM}$ of docetaxel, for 3, 6 and 24 hours. The luciferase and renilla activities were measured using a Dual-Luciferase ${ }^{\circledR}$ reporter assay (Promega). The NF- $\kappa$ B transcriptional activity was expressed as fold change of Relative Luciferase Units (ratio between luciferase light values divided by the renilla light values), taking the untreated controls as the baseline.

\section{Statistical analysis}

Statistical analysis was carried out using independent samples student $\mathrm{t}$-tests. Results were considered statistically significant where $\mathrm{p}<0.05$ and results are expressed as mean \pm the standard deviation.

\section{Results}

Effects of Docetaxel on (A) Apoptosis and (B) Proliferation in the Docetaxel resistant sublines

Figure 1A demonstrates the apoptotic effects of two different concentrations of Docetaxel ( $20 \mathrm{nM}$ and $80 \mathrm{nM}$ ) for 48 hours on the four different Docetaxel resistant sublines. PC-3 D8 and PC-3 D12 demonstrated partial but increasing resistance to docetaxel treatment over the different doses, when compared to the PC-3 Ag. The DU-145 R and 22RV1 $R$ showed significantly more resistance compared to the aged matched control cells (DU-145 Ag \& 22RV1 Ag). Cell viability was then determined by the MTT assay (B), following treatment with docetaxel (10 nM, $20 \mathrm{nM}, 50 \mathrm{nM}$ and $100 \mathrm{nM})$ for 24 , 48 and 72 hours. The PC-3 Ag cells had an $\mathrm{IC}_{50} @ 48$ hrs = $10 \mathrm{nM}$, the PC-3 D8 an $\mathrm{IC}_{50} @ 48 \mathrm{hrs}=20 \mathrm{nM}$ and the PC-3 D12 an $\mathrm{IC}_{50} @ 48 \mathrm{hrs}=100$ nM following treatment with Docetaxel (Figure 1B). This confirmed that the PC-3 D8 and PC-3 D12 sublines had a resistance to Docetaxel treatment.

\section{P-glycoprotein (P-gp) expression in the Docetaxel resistant sub-lines}

We next wanted to investigate the mechanisms responsible for Docetaxel resistance. We firstly examined the expression of the classical drug pump, P-gp (Mdr-1) in the PC-3 D8 and PC-3 D12 sublines compared to the PC-3 Ag subline. Figure 2A clearly shows no expression of P-gp in any of the PC-3 sublines, when compared to the P-gp positive cell line (DLKP-A, Figure 2A), and the DLKP negative cell line, as previously described [19].

We further confirmed P-gp was not playing a role in this resistance by blocking P-gp activity with the P-gp inhibitor, Elacridar $(0.25$ and $0.5 \mu \mathrm{M})$ [20,21]. Following 24 hours, pre-treatment, Elacridar had no effect on the cells susceptibility to Docetaxel (20 nM) induced apoptosis over 48 hours. However, as a positive control the P-gp over expressing cell line NCI/ADR/RES (ovarian cancer cell line) underwent increased levels of apoptosis 


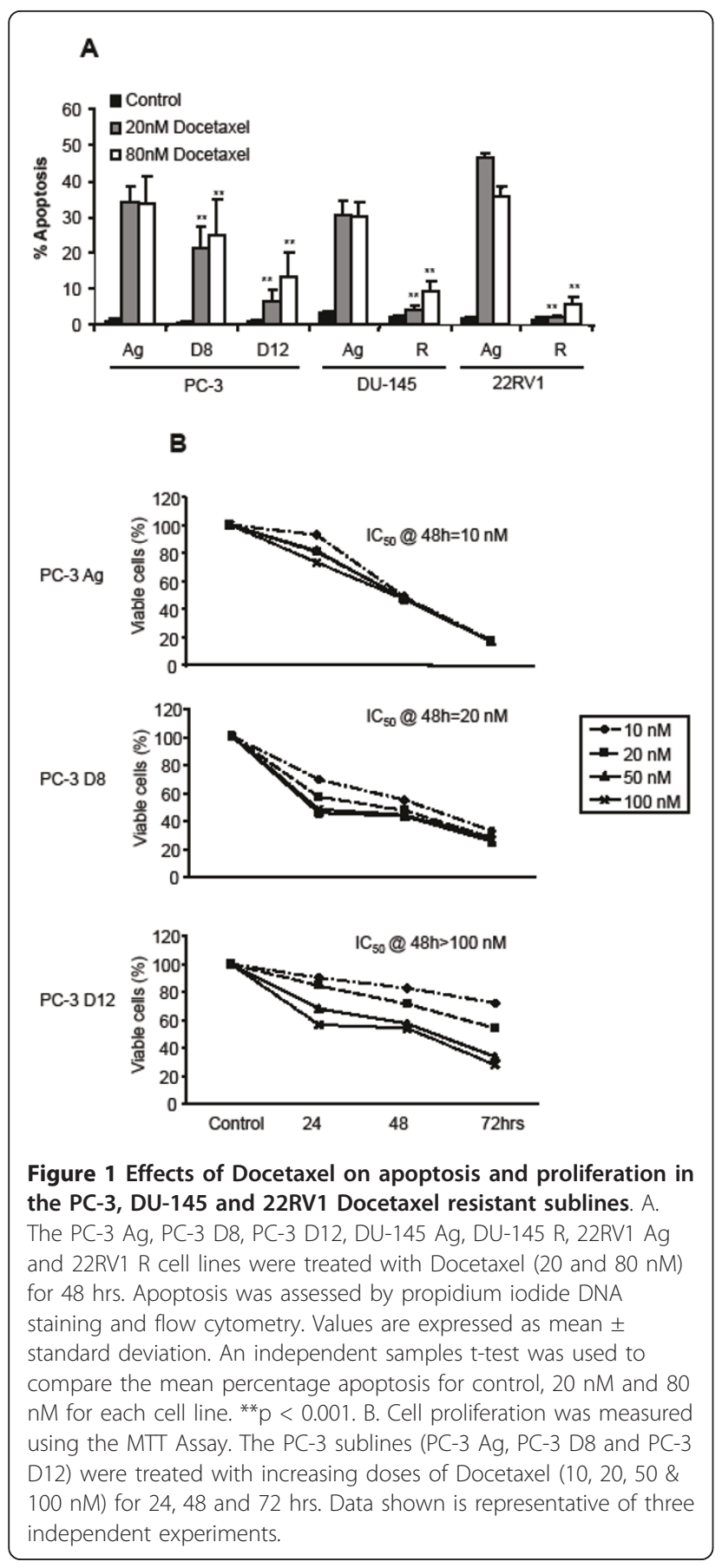

following treatment with Docetaxel $(20 \mathrm{nM})$ after 48 hours (Figure 2B).

Similar experiments were carried out with the DU-145 $\mathrm{R}$ and 22RV1 $\mathrm{R}$ sublines. Western blotting demonstrated expression of P-gp in the DU-145 R and 22RV1 R sublines with higher expression in the 22RV1 R (Figure $2 \mathrm{C})$. Elacridar treatment $(0.25$ and $0.5 \mu \mathrm{M})$ also partially reversed the resistance to apoptosis in the DU-145 R cells and totally reversed the resistance in the 22RV1 R sublines following treatment with Docetaxel (20 nM) for 48 hours (Figure 2D). As the resistance to Docetaxel induced apoptosis may be partially explained by the over expression of P-gp in the DU-145 R and 22RV1 R cells we focused on the PC-3 D8 and PC-3 D12 sublines whose resistance was not P-gp dependent.

\section{Cellular senescence and autophagy as mechanisms of Docetaxel resistance}

Senescent cells demonstrate resistance to apoptosis and express $\beta$-galactosidase. The effects of Docetaxel treatment (100 nM for 48 hours) on PC-3 Ag, PC-3 D8 and PC-3 D12 cellular senescence is demonstrated in Figure 3 which shows no significant increase in $\beta$-galactosidase staining.

Autophagy (macroautophagy) is also a well conserved mechanism by which cells adapt to stress such as starvation [22]. This complex cellular process has recently been associated with resistance to cancer therapies [23]. Total cellular protein was extracted from the different cell lines following Docetaxel treatment $(50 \mathrm{nM})$ and assessed for the expression of LC3 II, a protein associated with autophagosome formation and a marker of autophagy [24]. While the resistant PC-3 D12 sub-lines showed a higher baseline expression of LC3I, the precursor of LC3II, no consistent difference in the baseline expression levels of LC3II was demonstrated between the PC-3 Ag and the resistant PC-3 D12 subline (Figure 4) following treatment.

\section{Altered expression of apoptotic related genes in the Docetaxel resistant sublines}

Having ruled out P-gp, senescence and autophagy as possible mechanisms of resistance in the $\mathrm{PC}-3$ resistant sublines we next investigated other mechanisms and focused on the alteration in genes and proteins which regulate cellular apoptosis. Custom designed Low Density Arrays (LDA) which included the probes for the IAPs, death receptors, death ligands, and signalling molecules as well as genes involved in cell cycle regulation, DNA damage and repair and chemotherapy resistance were developed. Additional file 1, lists the 95 genes chosen for inclusion and their function.

Table 1 demonstrates the genes which were increased in the PC-3 D8 subline compared to the PC-3 Ag cells. The majority of these genes are anti-apoptotic including BIRC7 (Livin-a member of the IAP family), Bcl2-A1 (Bcl-2 member), Foxo1A and HSP 90. Clusterin, a molecular chaperone was also found to be increased. TNF receptor family member $10 \mathrm{C}$, which is known to inhibit TRAIL-induced apoptosis, was also increased in this subline. Nibrin and p73 which are involved in DNA damage and repair were also up-regulated. Table 2 demonstrates the genes which were down-regulated in 


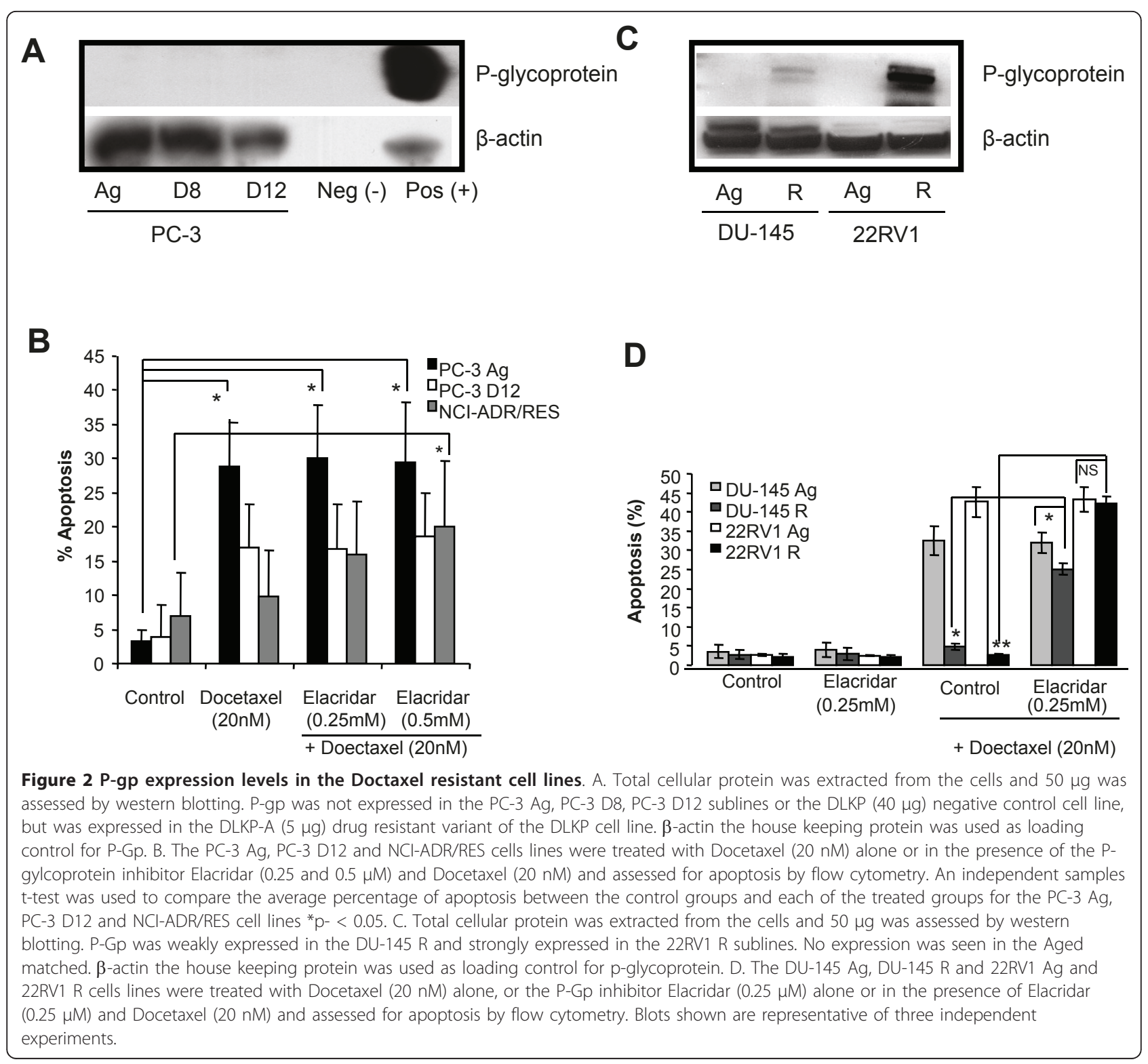

the PC-3 D8 subline compared to the PC-3 Ag cells. A number of genes involved in the induction of apoptosis were shown to be changed. These include; FOXO1, NGFR, TRAF-1, and TRAF-2. Surprisingly a number of anti-apoptotic genes were also decreased including; MCL-1 and BIRC3.

Genes increased in the PC3-D12 subline compared to the PC-3 Ag cells are represented in Table 3. Many of the increased genes are anti-apoptotic genes such as BIRC1, BCL2-A1, FOXO1A, NOL3 and Clusterin. Genes involved in DNA damage and repair such as Nibrin, Chek-1 and ATM were also increased. Decreased gene expression in the PC3-D12 subline compared to the PC-3 Ag cells is demonstrated in Table 4. Many of these genes are those involved in the induction of apoptosis. These include BOK, NGFR, Fas, FasLG, TNF receptor member $11 \mathrm{~b}$, TRAF-1 and TRAIL. A number of genes involved in cell cycle regulation and DNA damage detection were also decreased. These include Chek2, p21, ETS2 and ATR.

\section{Validation of altered gene expression}

We next wanted to validate specific genes at the protein level. Total cellular protein was extracted from the PC-3 Ag, PC-3 D8 and PC-3 D12 and assessed by western blotting for Clusterin, Id-1, Bcl-2, Bcl-xL, Bid and Bax. As demonstrated in Figure 5, Id-1 expression was increased in the PC-3 D12 subline only, while the protein expression of Bcl-2 was increased in PC-3 D8 but not in PC-3 D12. Anti-apoptotic Bcl-xL was increased 


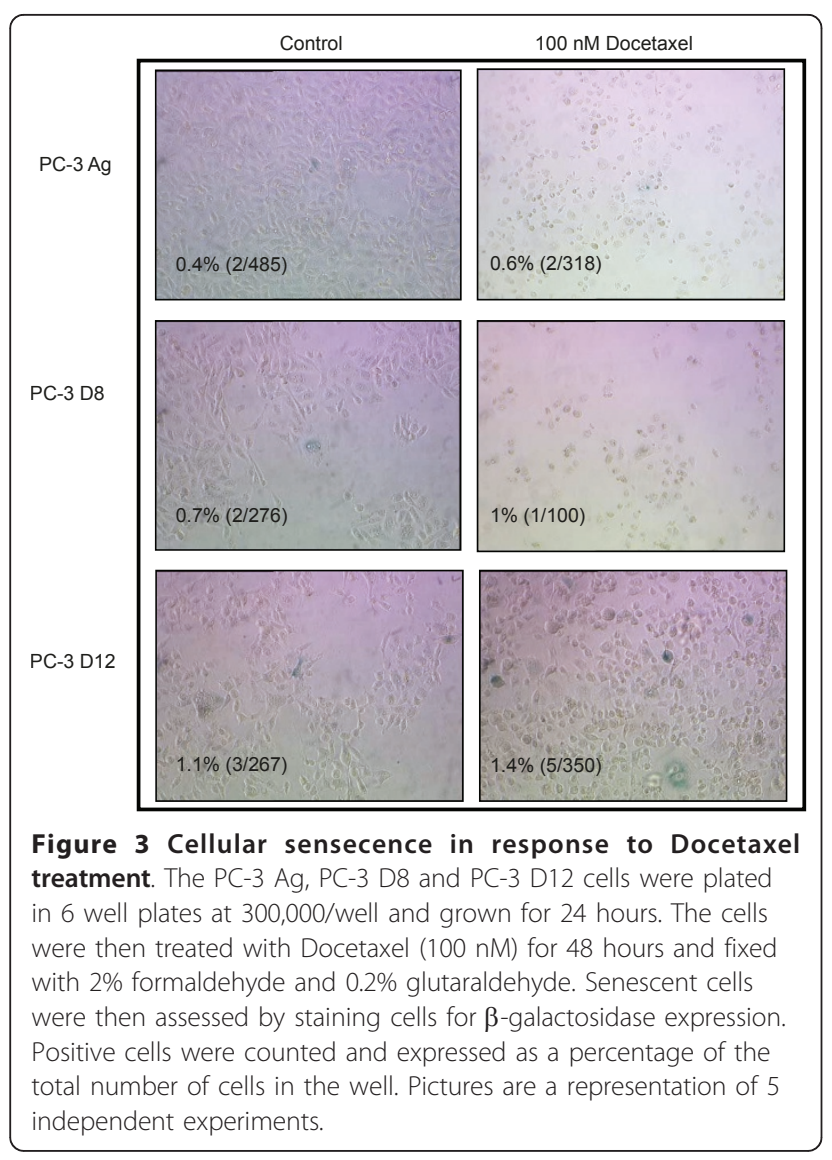

in both sublines. Pro-apoptotic protein Bid was decreased in PC-3 D12 while Bax was decreased in both sublines. Clusterin was significantly increased in both sublines. The molecular chaperone HSP90 was also increased in both sublines (Figure 5).

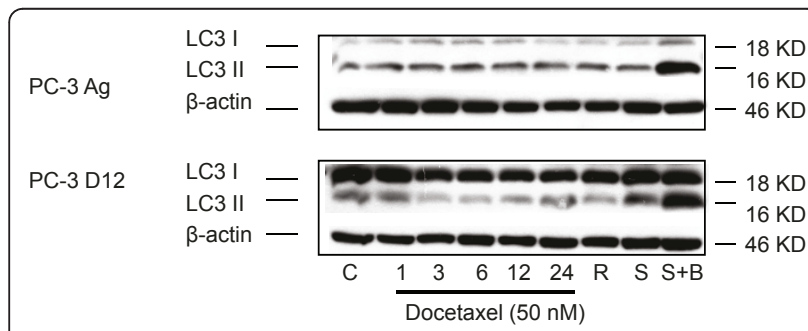

Figure 4 Autophagy as a mechanisms of Docetaxel resistance Following treatment of the Aged matched controls (Upper panel) and PC-3 D12 resistant sublines (Bottom panel) with $50 \mathrm{nM}$ of Docetaxel for 1, 3, 6, 12 and 24 hrs, total cellular protein was extracted and assessed for LC3II by western blotting using the relevant anti-body and conditions as described in the methods section. For positive controls cells were either treated with Rapamycin (R, $0.2 \mu M)$ for 4 hrs, Starvation (S, the cells were starved in EBSS (Earls Balanced Salt Solution) medium for 2 hrs), or Starvation plus Bafilomycin ( $\mathrm{S}+\mathrm{B}, 20 \mathrm{nM})$ for 2 hrs. $\beta$-actin the house keeping protein was used as loading control. Blots shown are representative of three independent experiments.
Table 1 Genes increased in the PC-3 D8 Docetaxel Resistant Cell line

\begin{tabular}{|c|c|c|c|}
\hline $\begin{array}{l}\text { PC-3 D8 vs PC-3 Ag Gene } \\
\text { Name }\end{array}$ & Accession no. & $\frac{\text { Fold }}{\text { change }}$ & $\underline{p \text { value }}$ \\
\hline BIK & NM_001197 & 4.606724005 & 0.024378 \\
\hline FOXO1 & NM_002015 & 4.092077589 & 0.006372 \\
\hline NAIP & NM_004536 & 3.895819042 & NA \\
\hline HSP90AA1 & NM_001017963 & 2.255183574 & 0.116769 \\
\hline IL8 & NM_000584 & 2.194814925 & 0.060076 \\
\hline $\mathrm{BCL} 2 \mathrm{~A} 1$ & NM_001114735 & 2.003718027 & 0.018472 \\
\hline NBN & NM_002485 & 1.994366021 & 0.011912 \\
\hline TNFRSF10C & NM_003841 & 1.931533233 & 0.288353 \\
\hline TP73 & NM_001126240 & 1.785086313 & 0.082871 \\
\hline BNIP3L & NM_004331 & 1.747205486 & 0.03454 \\
\hline CLU & NM_001171138 & 1.740002897 & 0.304795 \\
\hline APAF1 & NM_001160 & 1.673345235 & 0.38724 \\
\hline FASLG & NM_000639 & 1.563978305 & 0.73945 \\
\hline BNIP3 & NM_004052 & 1.50139036 & 0.173556 \\
\hline
\end{tabular}

Pre-designed TaqMan probe and primer sets for target genes were chosen from an on-line catalogue (Applied Biosystems). Expression levels of target genes were normalised to concentration of 18S rRNA (Additional File 1 lists the 95 genes chosen for inclusion and their function). Total mRNA was extracted from the PC-3 Ag and PC-3 D8 cells and used on custom designed Low Density Arrays (LDA) to determine which genes were increased (fold increase $>1.5$ ) in the Docetaxel resistanct PC-3 D8 subline compared to the PC-3 Ag. $\mathrm{n}=3$.

Docetaxel treatment increases NF- $\kappa$ B activity in the PC-3 D12 resistant $\mathrm{PC}-3$ subline

As NF- $\kappa$ B regulated the expression of a number of the apoptotic genes listed in Tables 1, 2, 3 and 4, we next

Table 2 Genes decreased in the PC-3 D8 Docetaxel Resistant Cell line

\begin{tabular}{|c|c|c|c|}
\hline $\begin{array}{l}\text { PC-3 D8 vs PC-3 Ag } \\
\text { Gene Name }\end{array}$ & Accession no. & Fold change & $\underline{p \text { value }}$ \\
\hline$\overline{B A G 1}$ & NM_001172415 & 0.485055 & 0.102992 \\
\hline MCL1 & NM_021960 & 0.464403 & 0.048121 \\
\hline ID1 & NM_002165 & 0.460689 & 0.434385 \\
\hline ATR & NM_001184 & 0.435832 & 0.039411 \\
\hline PTEN & NM_000314 & 0.422497 & 0.245383 \\
\hline NGFR & NM_002507 & 0.391286 & 0.285516 \\
\hline BNIP2 & NM_004330 & 0.36245 & 0.124787 \\
\hline JUN & NM_002228 & 0.339603 & 0.18277 \\
\hline BIRC3 & NM_001165 & 0.313233 & 0.006408 \\
\hline BMF & NM_001003940 & 0.292831 & 0.104867 \\
\hline DDIT3 & NM_001195053 & 0.279562 & 0.157249 \\
\hline TRAF1 & NM_001190945 & 0.269089 & 0.18055 \\
\hline IL6 & NM_000600 & 0.190685 & 0.031992 \\
\hline IGF1R & NM_000875 & 0.160304 & 0.013039 \\
\hline MAPK10 & NM_002753 & 0.123932 & NA \\
\hline TNFSF10 & NM_001190942 & 0.115113 & 0.175825 \\
\hline BIRC8 & NM_033341 & 0.024782 & 0.517705 \\
\hline TNFRSF10D & NM_003840 & 0.011276 & 0.144385 \\
\hline
\end{tabular}

Genes whose expression has decreased (fold increase $<0.5$ ) in the Docetaxel resistant PC-3 D8 subline compared to the PC-3 Ag. $n=3$. 
Table 3 Genes increased in the PC-3 D12 Docetaxel Resistant Cell line

\begin{tabular}{|c|c|c|c|}
\hline $\begin{array}{l}\text { PC-3 D12 vs PC-3 Ag Gene } \\
\text { Name }\end{array}$ & Accession no. & $\frac{\text { Fold }}{\text { change }}$ & $\underline{p}$ value \\
\hline NAIP & NM_004536 & 28.14023 & NA \\
\hline BCL2A1 & NM_001114735 & 9.956213 & 7.84E-06 \\
\hline CLU & NM_001171138 & 6.138126 & 0.019757 \\
\hline TNFRSF1B & NM_001066 & 4.568718 & NA \\
\hline ATM & NM_000051 & 2.884063 & 0.013665 \\
\hline FOXO1 & NM_002015 & 2.746056 & 0.0167 \\
\hline MAP2K4 & NM_003010 & 2.456245 & 0.13486 \\
\hline APAF1 & NM_001160 & 2.264102 & 0.34641 \\
\hline NOL3 & NM_001185057 & 1.946074 & 0.101148 \\
\hline CHEK1 & NM_001114121 & 1.554884 & 0.433367 \\
\hline BNIP3L & NM_004331 & 1.514918 & 0.113779 \\
\hline NBN & NM_002485 & 1.505995 & 0.051555 \\
\hline \multicolumn{4}{|c|}{$\begin{array}{l}\text { Total mRNA was extracted from the PC-3 Ag and PC-3 D12 cells and used on } \\
\text { custom designed Low Density Arrays (LDA) which included the transcriptional } \\
\text { profile probes for the IAPs, death receptors, death ligands, and signalling } \\
\text { molecules as well as genes involved in cell cycle regulation, DNA damage and } \\
\text { repair and chemotherapy resistance. Additional File } 1 \text {, lists the } 95 \text { genes } \\
\text { chosen for inclusion, and their function. Genes whose expression has } \\
\text { increased (fold increase }>1.5 \text { ) in the Docetaxel resistanct PC-3 D12 subline } \\
\text { compared to the PC-3 Ag. } n=3 \text {. }\end{array}$} \\
\hline
\end{tabular}

wanted to determine whether NF- $\kappa$ B played a role in the resistance to Docetaxel. We firstly assessed the baseline transcriptional activity in the $\mathrm{PC}-3$ resistant subline using a luciferase assay. Interestingly, NF- $\kappa \mathrm{B}$ transcriptional activity was significantly decreased $(p<0.001)$ in the resistant PC-3 D12 subline compared to the PC-3 Ag cells (Figure 6A). The DU145 cell lines showed a similar trend with decreased NF- $\kappa \mathrm{B}$ transcriptional activity in the resistant subline (DU-145 R) compared to the parental (DU-145 Ag); while there was no difference in NF- $\kappa \mathrm{B}$ activity in the aged (22RV1 Ag) matched and resistant 22RV1 (22RV1 R), being the baseline NF- $\kappa \mathrm{B}$ activity in these cells was very low in comparison to the PC-3 and DU145 cells (data not shown). NF- $\kappa$ B decreased activity in the resistant PC-3 sublines was confirmed by the TransAM ELISA based assay which showed a significant decrease in the activity of p52 ( p < $0.01)$ and RelB $(p<0.05)$ subunits, in both the PC-3 D8 and PC-3 D12 resistant cells compared to the PC-3 Ag (Figure 6B).

We then assessed the effects of Docetaxel treatment on NF- $\kappa \mathrm{B}$ transcriptional activity in the resistant subline. Following Docetaxel treatment there was significantly increased transcriptional activity in the PC-3 D12 resistant subline compared to the PC-3 Ag cells (Figure 7A). There was no increase in the DU-145 R subline (Figure $7 \mathrm{~A}$ ), and there was no NF- $\kappa \mathrm{B}$ activity in the 22RV1 cells neither in response to docetaxel or to the classical NF- $\kappa$ B inducers such as TNF $\alpha$ or LPS (data not shown). Activation of NF- $\kappa \mathrm{B}$ in the resistant PC-3 D12 subline compared to the PC-3 Ag cells was
Table 4 Genes decreased in the PC-3 D12 Docetaxel Resistant Cell line

\begin{tabular}{|c|c|c|c|}
\hline $\begin{array}{l}\text { PC-3 D12 vs PC-3 Ag Gene } \\
\text { Name }\end{array}$ & Accession no. & $\frac{\text { Fold }}{\text { change }}$ & $\underline{p \text { value }}$ \\
\hline XIAP & NM_001167 & 0.481312 & 0.176898 \\
\hline CHEK2 & NM_001005735 & 0.475224 & 0.131629 \\
\hline JUN & NM_002228 & 0.46633 & 0.309774 \\
\hline BCL2L2 & NM_004050 & 0.45255 & 0.082823 \\
\hline TRAF2 & NM_021138 & 0.443326 & 0.006969 \\
\hline DDIT3 & NM_001195053 & 0.432559 & 0.452576 \\
\hline BCL2L11 & NM_006538 & 0.432054 & 0.074605 \\
\hline CDKN1A & NM_000389 & 0.42579 & 0.080132 \\
\hline ETS2 & NM_005239 & 0.382415 & 0.00487 \\
\hline IL8 & NM_000584 & 0.369938 & 0.022567 \\
\hline FAS & NM_000043 & 0.336752 & 3.61E-05 \\
\hline ATR & NM_001184 & 0.315906 & 0.010488 \\
\hline BOK & NM_032515 & 0.298213 & 0.014457 \\
\hline NGFR & NM_002507 & 0.289875 & 0.003775 \\
\hline $\mathrm{ABCB} 1$ & NM_000927 & 0.254066 & NA \\
\hline FASLG & NM_000639 & 0.251687 & 0.330804 \\
\hline BIK & NM_001197 & 0.249128 & 0.04058 \\
\hline XAF1 & NM_017523 & 0.196716 & 0.637745 \\
\hline VEGFA & NM_001025366 & 0.147831 & 0.017993 \\
\hline TRAF1 & NM_001190945 & 0.13621 & 0.030832 \\
\hline BIRC3 & NM_001165 & 0.102653 & 0.000293 \\
\hline TNFRSF11B & NM_002546 & 0.099691 & 0.005951 \\
\hline TNFRSF10D & NM_003840 & 0.085696 & 0.332193 \\
\hline EGR1 & NM_001964 & 0.0682 & 0.005374 \\
\hline TP73 & NM_001126240 & 0.026123 & 0.004742 \\
\hline BIRC8 & NM_033341 & 0.024998 & 0.523298 \\
\hline TNFSF10 & NM_001190942 & 0.01728 & 0.053714 \\
\hline IL6 & NM_000600 & 0.011894 & 0.000652 \\
\hline
\end{tabular}

Genes whose expression has decreased (fold increase $<0.5$ ) in the Docetaxel resistanct PC-3 D12 subline compared to the PC-3 Ag. $n=3$.

confirmed by western blotting showing higher levels of phospho- $\mathrm{\kappa} \kappa \mathrm{B} \alpha$ in the PC-3 D12 compared to the PC-3 Ag, following 3-6 h of docetaxel treatment (Figure 7B). NF $-\kappa B$ was functionally confirmed to be centrally involved in resistance to Docetaxel using the NF- $\kappa \mathrm{B}$ inhibitor (BAY 11-7082, Merck) which reversed resistance in both the PC-3 D8 and PC-3 D12 sublines (Figure 8).

\section{Discussion}

The treatment of advanced prostate cancer represents a significant challenge due to the accumulation of multiple mechanisms of drug resistance. Resistance to Docetaxel treatment includes changes in classical multiple drug resistant pathways, expression of different $\beta$-tublin isotypes, mutations in tumour suppressor proteins and altered expression of pro- and anti-apoptotic proteins [25]. We have generated three models of docetaxelresistance in prostate cancer cells which may mimic the 


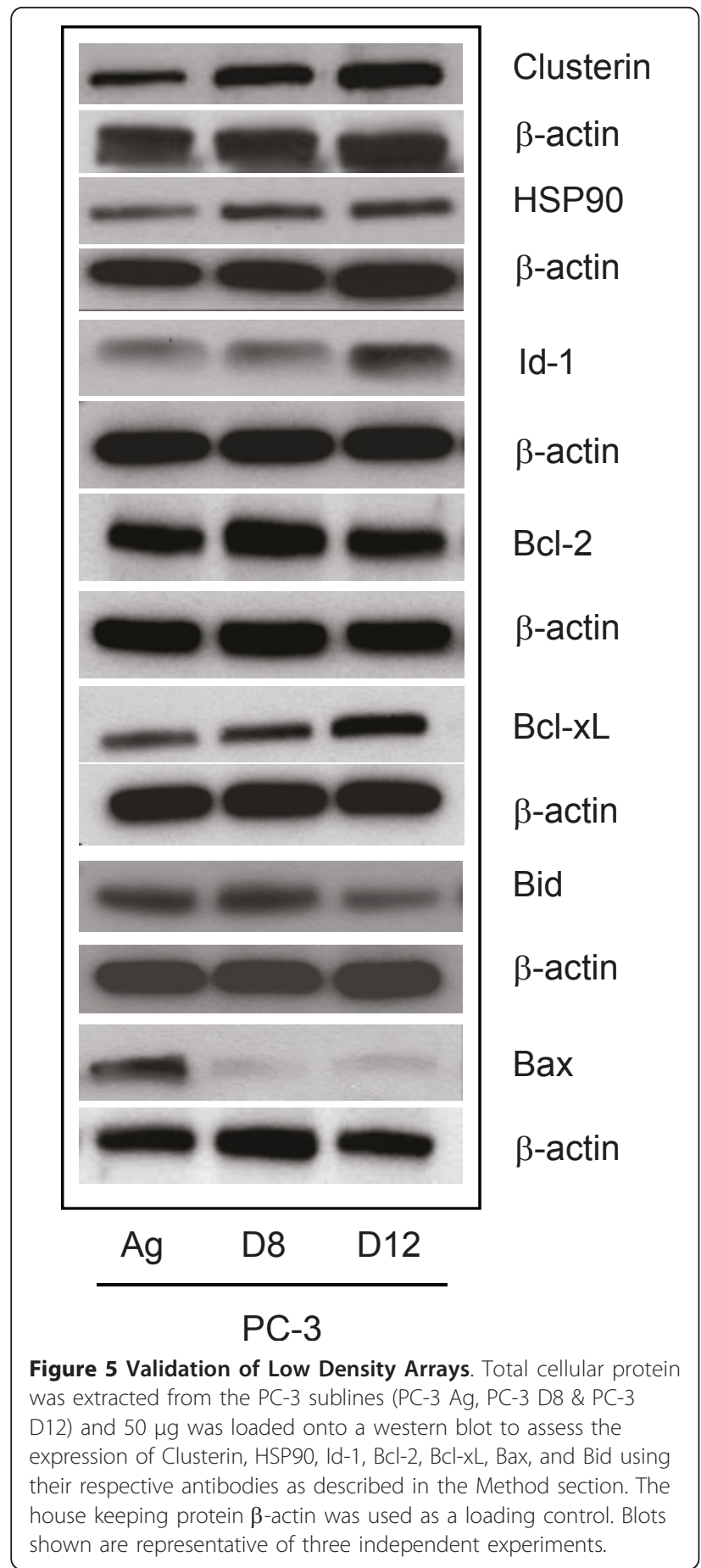

situation in the clinical setting and used them to understand the complexity of mechanisms leading to treatment resistance. Understanding these pathways will be essential if we want to better impact on the outcome of these patients and identify additional cotreatments which will manipulate this resistance and develop personalised treatments. We demonstrated
A

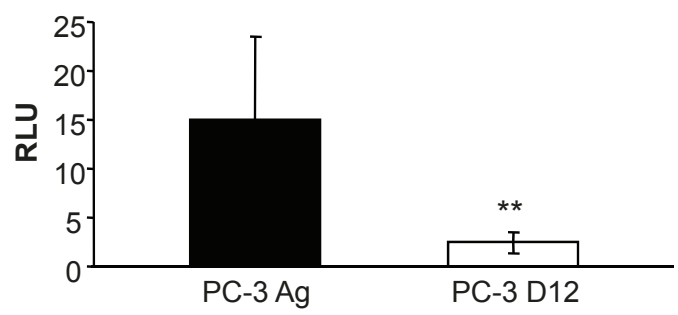

B

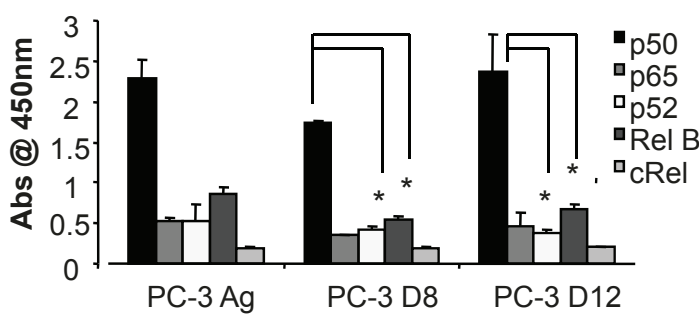

Figure $6 \mathrm{NF}-\kappa \mathrm{B}$ transcriptional activity and Baseline NFkB subunit activity. A. PC-3 Ag and PC-3 D12 cells were plated at 100,000/per well and grown for 24 hours. The baseline NF $\kappa$ B activity was assessed by luciferase assay, using a Dual Luciferase Assay from Promega following the manufactures instructions. Averages from 3 independent experiments are shown. Mean values were compared using t-test assuming equal variances. B. The PC-3 Ag and PC-3 D12 cells were grown to confluency and nuclear extracts prepared as per the TransAMTM Assay Kit manual. Averages from 3 independent experiments are shown. Mean values were compared using t-test assuming equal variances.

that all four sublines are resistant to increasing concentrations of Docetaxel as assessed by apoptosis and viability assays.

One of the main mechanisms of resistance to Docetaxel is the over expression of P-gp [4] which would reduce intracellular concentrations of the drug through increased efflux. Chemoresistant PC-3 cells do not over express P-gp, while resistant DU145 cells exhibit both over expression of the protein and restored chemosensitivity with P-gp inhibition $[5,26]$. This has been the basis for the development of cabazitaxel which can overcome P-gp over expression [27] and is now used as a second line therapy for patients who fail Docetaxel treatments. In our study we demonstrated that the resistance in the PC-3 D8 and PC-3 D12 sublines was independent of $\mathrm{P}$-gp over expression as there were no detectable levels and no effects of the P-gp inhibitor Elacridar on their resistance. However the DU-145 and 22RV1 cells expressed increasing levels of P-gp and Elacridar totally reversed the resistance in the 22RV1 and partially in the DU145 resistant sublines. Based on these results we focused on the PC-3 cells to understand the mechanisms of resistance independent of P-gp. 


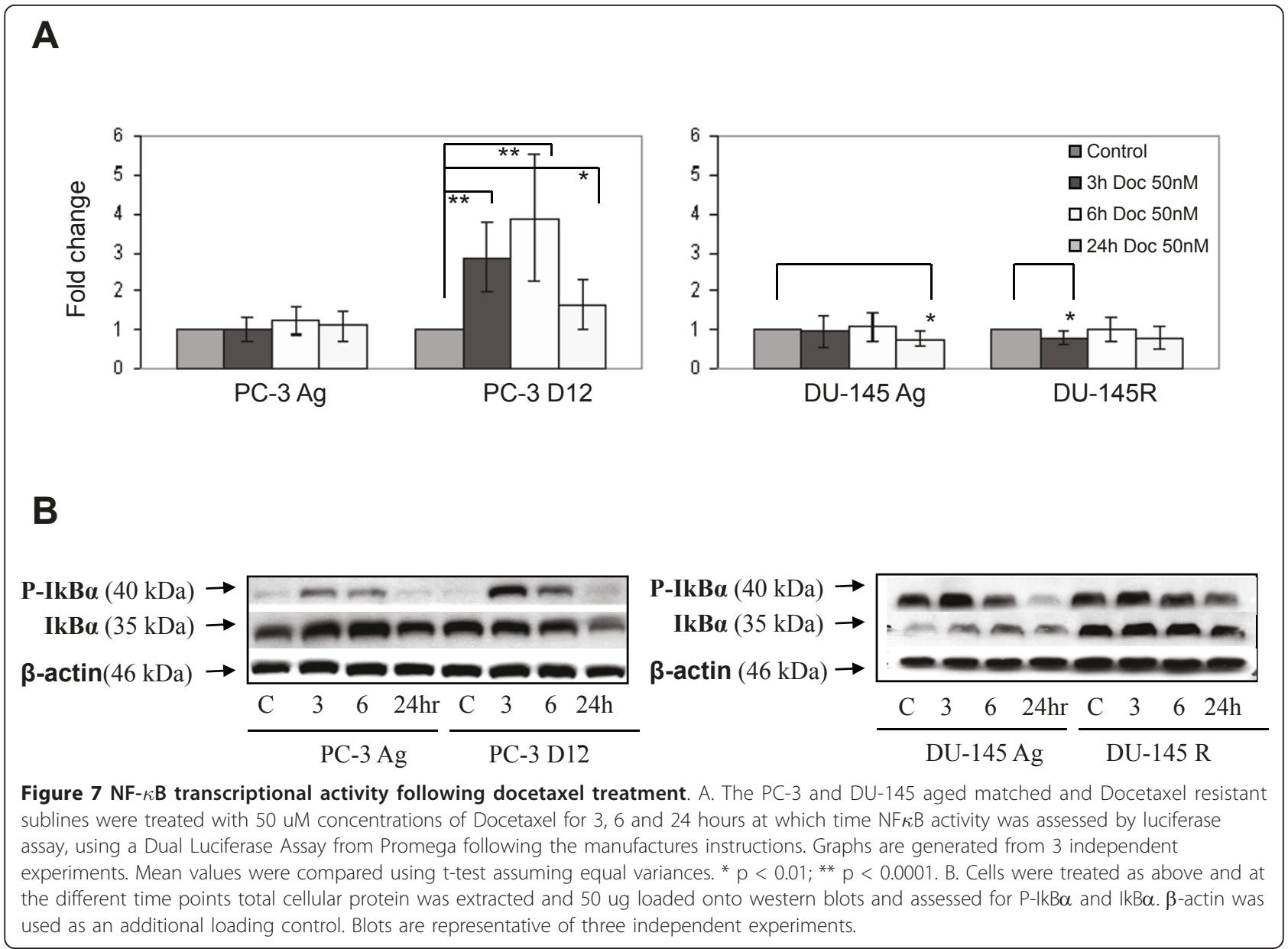

We next investigated cellular senescence as a possible mechanism of resistance. Premature cellular senescence, a phenomenon by which cells stop dividing and acquire a typical morphology and an altered gene expression profile in response to stress [3], has recently been associated with chemotherapy resistance. We performed a $ß$-galactosidase assay to assess cellular senescence following docetaxel treatment. Although $ß$-galactosidase

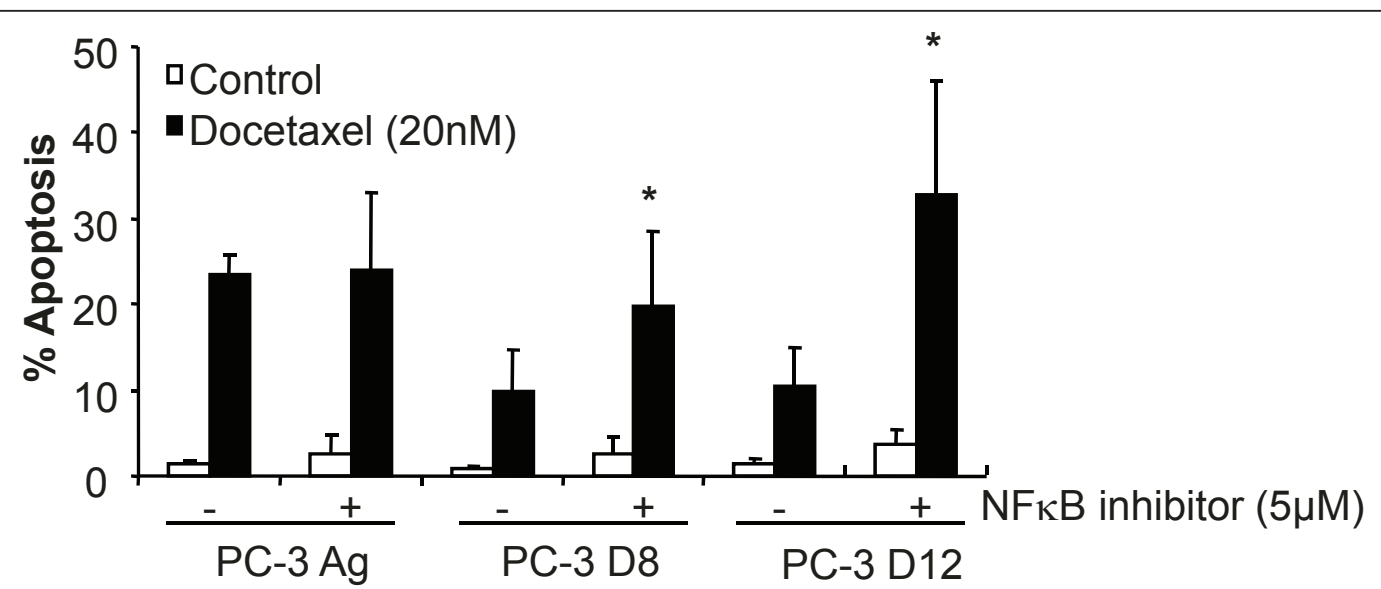

Figure $8 \mathbf{~ N F - ~} \kappa$ B inhibitor studies following docetaxel treatment. The PC-3 sublines where pre-treated with the NF $\kappa$ B inhibitor (BAY 11-7082, $5 \mu \mathrm{M})$ for 24 hours followed by Docetaxel $(20 \mathrm{nM})$ for a further 48 hours and assessed for apoptosis by flow cytometry. Graphs represent the results of 3 independent experiments. Mean values were compared using t-test assuming equal variances. ${ }^{*} p<0.05$. 
staining showed a modest increase in the percentage of senescent cells following docetaxel treatment, this increase was considered to be insufficient to explain the resistance of the PC-3 D8 and PC-3 D12 sublines to docetaxel.

Autophagy (macroautophagy), a well conserved mechanism by which cells adapt to stress such as starvation, has also been recently associated with resistance to cancer therapies [23]. Therefore we investigated whether increased autophagy was involved in the resistance to docetaxel in the PC-3 D12 subline. Although western blotting showed increased expression of the autophagic marker LC3II in the PC-3 D12 compared to the PC-3 Ag cells following docetaxel treatment, this was only a modest effect. Interestingly, the resistant PC-3 D12 subline showed a higher baseline expression of LC3I, the precursor of LC3II, which warrants further investigation.

We next undertook to assess alterations in the apoptotic phenotype of the resistant cells in order to understand the mechanisms involved. Custom-designed LDA containing real-time PCR assays for all the key apoptotic genes including the IAPs, death receptors, death ligands, and signalling molecules as well as genes involved in cell cycle regulation, DNA damage and repair were developed. The LDA results showed a complex interplay between changes in the expression of both pro- and anti-apoptotic proteins. From our study, genes which were shown to be altered in both the docetaxel-resistant sublines (PC-3 D8 and PC-3 D12) included; FOXO1, NGFR, TRAF-1, Mcl-1, BIRC3, BIRC1, Bcl-2-A1, NOL3, Clusterin, BOK, NGFR, Fas, FasLG, TNF receptor member $11 \mathrm{~b}$ and TRAIL.

Trougakos et al demonstrated that secreted clusterin (sCLU) knockdown in human prostate cancer cells induces significant reduction of cellular growth and higher rates of spontaneous endogenous apoptosis [28]. sCLU is a cytoprotective chaperone that stabilizes conformations of proteins during times of cellular stress, thereby inhibiting protein aggregation and precipitation [29]. Additionally, sCLU can interact with and inhibit activated Bax, thereby inhibiting cytochrome $\mathrm{C}$ release and caspase activation [30]. In prostate cancer, sCLU levels have previously been correlated with Gleason grade [31]. A recent publication identified sCLU to be over-expressed in a docetaxel-resistant PC-3 subline and reported that knockdown of sClu chemosensitizes this cell line to taxane and mitoxantrone based chemotherapy both in vitro and in vivo [32].

$\mathrm{Bcl}-2$ related protein A1 (Bcl2-A1) or BLF1 is a member of the Bcl-2 family. Although it is regulated differently from Bcl-2, it has similar anti-apoptotic activity. A recent publication demonstrated that $\mathrm{Bcl} 2-\mathrm{A} 1$ mediates resistance to doxorubicin in haematopoietic cell lines [33].
Modur et al found that FOXO1A was highly expressed in normal prostate. They also noted that in PTEN-deficient prostate carcinoma cell lines, FOXO1A was cytoplasmically sequestered and inactive and expression of TRAIL, a pro-apoptotic effector, was decreased. They determined that TRAIL is a direct target of FOXO1A, and they hypothesized that the loss of PTEN contributes to increased tumour cell survival through decreased transcriptional activity of FOXO1A and FOXO3A followed by decreased TRAIL expression and apoptosis [34].

BNIP3L which is also elevated in both sublines, plays a pro-survival role in apoptosis. Yasuda et al showed that in vitro translated BNIP3L binds specifically and directly with GST fusion proteins of various Bcl-2 family anti-apoptosis proteins, suggesting that, like BNIP3, BNIP3L may antagonize the activity of Bcl-2 family antiapoptosis proteins [35]. In this setting, BNIP3L may be increased in our resistant sublines in an attempt to antagonize the very elevated levels of Bcl2-A1.

Genes down-regulated in both sublines include TRAIL, NGFR, TNF member 10D and ATR among others (see Tables 1, 2, 3 and 4 results). As PC-3 cells are highly resistant to TRAIL, it is unsurprising that levels of pro-apoptotic TRAIL are further decreased in the resistant sublines. Tumour necrosis factor superfamily member 10D (TNF member 10D) has been shown to act as a decoy receptor for TRAIL (TRAIL R4). Transient over-expression of TRAIL R4 in cells normally sensitive to TRAIL-mediated apoptosis conferred complete protection, and Degli-Esposti et al suggested that one function of TRAIL R4 may be the inhibition of TRAIL cytotoxicity [36]. As a large number of genes were either increased or decreased in the docetaxel-resistant sublines, targeting these individually may not lead to alterations in the resistant phenotype but understanding the central signalling pathways and transcription factors would represent a more appropriate therapeutic targeting approach.

NF- $\kappa B$ initiates the transcription of a wide variety of genes that code for angiogenic factors, cell adhesion molecules, anti-apoptotic factors, and cytokines, which are involved in cell survival, invasion, metastasis, and chemoresistance [37]. In addition to its role in oncogenesis, NF- $\kappa \mathrm{B}$ has been associated with chemoresistance in various models [38-40]. Recent focus on inhibition of NF- $\kappa$ B activity has identified a sensitisation to apoptosis induced by various apoptotic triggers, including Docetaxel in multiple cell lines including PC-3 cells [41]. Our low density array studies identified the up-regulation of a number of target genes of NF- $\kappa$ B (IAPs, IL-8, TNF receptor family members and FasLG). Based on these findings we focused our investigations towards the central role of NF- $\kappa \mathrm{B}$ in mediating the resistant phenotype. 
Despite a decrease in the baseline expression levels of the NF- $\kappa \mathrm{B}$ subunits p52 and RelB and transcriptional activity, when the cells were treated with Docetaxel there was an increase in NF- $\kappa \mathrm{B}$ transcriptional activity. This led us to the inhibition of NF- $\kappa \mathrm{B}$ activity using the NF- $\kappa$ B inhibitor BAY11-7082 prior to treatment with Docetaxel which resulted in significant reversal of Docetaxel resistance.

\section{Conclusion}

A mounting body of evidence implicates dysregulation of cell-survival signalling pathways in the pathogenesis of castration-resistant prostate cancer. What is not clear is which are the most salient targets in these pathways that when inhibited will lead to reversal of resistance and the most effective clinical outcome. An improved understanding of the molecular mechanisms regulating castration-resistant prostate cancer will drive both the identification of appropriate treatment strategies and biomarkers to inform such strategies. Our current results indicate that NF- $\kappa \mathrm{B}$ plays an important role in determining Docetaxel resistance and attempts to sensitise resistant prostate cancer cells to Docetaxel therapy should target this transcription factor.

\section{Additional material}

Additional file 1: List of genes on the Low Density Arrays. This table contains the list of 95 genes contained on the Low Density Arrays including gene name, gene symbol and gene function for each gene included on the array.

\section{Abbreviations \\ MDR: multi drug resistance; P-gp: p-glycoprotein; PI3K: phosphatidylinositol 3'-kinase}

\section{Acknowledgements}

We acknowledge the technical support of Dr Alfonso Blanco in the Flow Cytometry core facility and Ms. Catherine Moss in the Transcriptomics core facility of the UCD Conway Institute of Biomolecular and Biomedical Research. The work was funded by a Science Foundation Ireland, Strategic Research Cluster award to Molecular Therapeutics for Cancer Ireland (award 08/SRC/B1410).

\section{Author details}

${ }^{1}$ UCD School of Medicine and Medical Science, UCD Conway Institute of Biomolecular and Biomedical Research, University College Dublin, Dublin, Ireland. ${ }^{2}$ UCD School of Biomolecular and Biomedical Science, UCD Conway Institute of Biomolecular and Biomedical Research, University College Dublin, Dublin, Ireland. ${ }^{3}$ National Institute for Cellular Biotechnology, Dublin City University, Ireland. ${ }^{4}$ School of Pharmacy and Pharmaceutical Sciences, Trinity College Dublin, Dublin, Ireland.

\section{Authors' contributions}

AJON undertook the low density arrays and western blotting validation assays as well as preparing and writing the manuscript. MP undertook the NF-KB experiments as well as preparing and writing the manuscript. CD made the Docetaxel resitant PC-3 cell lines and performed the viability and apoptosis experiments. AJON, MP and CD contributed equally to the delivery of the manuscript. YF did the statistical analysis for the manuscript.
LM, WMG, and DOC undertook the NFKB Trans Am kit experiments. ROC and $A D$ examined the P-gp protein expression in the cell lines and provided the inhibitor. CC, SR and LOD made the DU-145 and 22RV1 Docetaxel resistant cell lines. JMF and RWGW conceived the study. RWGW was central in the design, coordination and manuscript editing. All authors have read and approved the final manuscript.

\section{Competing interests}

The authors declare that they have no competing interests.

Received: 18 July 2011 Accepted: 7 October 2011

Published: 7 October 2011

\section{References}

1. Mostaghel EA, Page ST, Lin DW, Fazli L, Coleman IM, True LD, Knudsen B, Hess DL, Nelson CC, Matsumoto AM, et al: Intraprostatic androgens and androgen-regulated gene expression persist after testosterone suppression: therapeutic implications for castration-resistant prostate cancer. Cancer Res 2007, 67:5033-5041.

2. Scher HI, Halabi S, Tannock I, Morris M, Sternberg CN, Carducci MA, Eisenberger MA, Higano C, Bubley GJ, Dreicer R, et al: Design and end points of clinical trials for patients with progressive prostate cancer and castrate levels of testosterone: recommendations of the Prostate Cancer Clinical Trials Working Group. J Clin Oncol 2008, 26:1148-1159.

3. Raghavan D, Koczwara B, Javle M: Evolving strategies of cytotoxic chemotherapy for advanced prostate cancer. Eur J Cancer 1997, 33:566-574.

4. van Brussel JP, Mickisch GH: Multidrug resistance in prostate cancer. Onkologie 2003, 26:175-181

5. Makarovskiy AN, Siryaporn E, Hixson DC, Akerley W: Survival of docetaxelresistant prostate cancer cells in vitro depends on phenotype alterations and continuity of drug exposure. Cell Mol Life Sci 2002, 59:1198-1211.

6. Shen MM, Abate-Shen C: Pten inactivation and the emergence of androgen-independent prostate cancer. Cancer Res 2007, 67:6535-6538.

7. Feldman BJ, Feldman D: The development of androgen-independent prostate cancer. Nat Rev Cancer 2001, 1:34-45.

8. McEleny K, Coffey R, Morrissey C, Williamson K, Zangemeister-Wittke $U$, Fitzpatrick JM, Watson RW: An antisense oligonucleotide to CIAP-1 sensitizes prostate cancer cells to fas and TNFalpha mediated apoptosis. Prostate 2004, 59:419-425.

9. Gibbons NB, Watson RW, Coffey RN, Brady HP, Fitzpatrick JM: Heat-shock proteins inhibit induction of prostate cancer cell apoptosis. Prostate 2000, 45:58-65.

10. Sternberg CN, Dumez H, Van Poppel H, Skoneczna I, Sella A, Daugaard G, Gil T, Graham J, Carpentier P, Calabro F, et al: Docetaxel plus oblimersen sodium (Bcl-2 antisense oligonucleotide): an EORTC multicenter, randomized phase II study in patients with castration-resistant prostate cancer. Ann Oncol 2009, 20:1264-1269.

11. De Marzo AM, Platz EA, Sutcliffe $S, X u$ J, Gronberg H, Drake CG, Nakai Y, Isaacs WB, Nelson WG: Inflammation in prostate carcinogenesis. Nat Rev Cancer 2007, 7:256-269.

12. McEleny K, Coffey R, Morrissey C, Fitzpatrick JM, Watson RW: Caffeic acid phenethyl ester-induced PC-3 cell apoptosis is caspase-dependent and mediated through the loss of inhibitors of apoptosis proteins. BJU Int 2004, 94:402-406.

13. Domingo-Domenech J, Oliva C, Rovira A, Codony-Servat J, Bosch M, Filella X, Montagut C, Tapia M, Campas C, Dang L, et al: Interleukin 6, a nuclear factor-kappaB target, predicts resistance to docetaxel in hormone-independent prostate cancer and nuclear factor-kappaB inhibition by PS-1145 enhances docetaxel antitumor activity. Clin Cancer Res 2006, 12:5578-5586.

14. Gill C, Dowling C, O'Neill AJ, Watson RW: Effects of CIAP-1, CIAP-2 and XIAP triple knockdown on prostate cancer cell susceptibility to apoptosis, cell survival and proliferation. Mol Cancer 2009, 8:39.

15. Prencipe $M$, Fitzpatrick $P$, Gorman $S$, Tosetto M, Klinger R, Furlong F, Harrison M, O'Connor D, Roninson IB, O'Sullivan J, McCann A: Cellular senescence induced by aberrant MAD2 levels impacts on paclitaxel responsiveness in vitro. Br J Cancer 2009, 101:1900-1908.

16. Dimri GP, Lee X, Basile G, Acosta M, Scott G, Roskelley C, Medrano EE, Linskens M, Rubelj I, Pereira-Smith $\mathrm{O}$, et al: A biomarker that identifies 
senescent human cells in culture and in aging skin in vivo. Proc Natl Acad Sci USA 1995, 92:9363-9367.

17. Maria McCrohan A, Morrissey C, O'Keane C, Mulligan N, Watson C, Smith J, Fitzpatrick JM, Watson RW: Effects of the dual 5 alpha-reductase inhibitor dutasteride on apoptosis in primary cultures of prostate cancer epithelial cells and cell lines. Cancer 2006, 106:2743-2752.

18. Walsh S, Gill C, O'Neill A, Fitzpatrick JM, Watson RW: Hypoxia increases normal prostate epithelial cell resistance to receptor-mediated apoptosis via AKT activation. Int J Cancer 2009, 124:1871-1878.

19. Collins DM, Crown J, O'Donovan N, Devery A, O'Sullivan F, O'Driscoll L, Clynes M, O'Connor R: Tyrosine kinase inhibitors potentiate the cytotoxicity of MDR-substrate anticancer agents independent of growth factor receptor status in lung cancer cell lines. Invest New Drugs 28:433-444.

20. Breedveld P, Beijnen JH, Schellens JH: Use of P-glycoprotein and BCRP inhibitors to improve oral bioavailability and CNS penetration of anticancer drugs. Trends Pharmacol Sci 2006, 27:17-24.

21. Hyafil F, Vergely C, Du Vignaud P, Grand-Perret T: In vitro and in vivo reversal of multidrug resistance by GF120918, an acridonecarboxamide derivative. Cancer Res 1209, 53:4595-4602.

22. Nakatogawa H, Suzuki K, Kamada Y, Ohsumi Y: Dynamics and diversity in autophagy mechanisms: lessons from yeast. Nat Rev Mol Cell Biol 2009, 10:458-467.

23. Morselli E, Galluzzi L, Kepp O, Vicencio JM, Criollo A, Maiuri MC, Kroemer G: Anti- and pro-tumor functions of autophagy. Biochim Biophys Acta 2009, 1793:1524-1532.

24. Klionsky DJ, Abeliovich $H$, Agostinis P, Agrawal DK, Aliev G, Askew DS, Baba M, Baehrecke EH, Bahr BA, Ballabio A, et al: Guidelines for the use and interpretation of assays for monitoring autophagy in higher eukaryotes. Autophagy 2008, 4:151-175.

25. Mahon KL, Henshall SM, Sutherland RL, Horvath LG: Pathways of chemotherapy resistance in castration-resistant prostate cancer. Endocr Relat Cancer 2011, 18:103-123.

26. Takeda M, Mizokami A, Mamiya K, Li YQ, Zhang J, Keller ET, Namiki M: The establishment of two paclitaxel-resistant prostate cancer cell lines and the mechanisms of paclitaxel resistance with two cell lines. Prostate 2007, 67:955-967.

27. de Bono JS, Oudard S, Ozguroglu M, Hansen S, Machiels JP, Kocak I, Gravis G, Bodrogi I, Mackenzie MJ, Shen L, et al: Prednisone plus cabazitaxel or mitoxantrone for metastatic castration-resistant prostate cancer progressing after docetaxel treatment: a randomised open-label trial. Lancet 376:1147-1154

28. Trougakos IP, So A, Jansen B, Gleave ME, Gonos ES: Silencing expression of the clusterin/apolipoprotein $\mathrm{j}$ gene in human cancer cells using small interfering RNA induces spontaneous apoptosis, reduced growth ability, and cell sensitization to genotoxic and oxidative stress. Cancer Res 2004, 64:1834-1842.

29. Shannan B, Seifert M, Leskov K, Willis J, Boothman D, Tilgen W, Reichrath J: Challenge and promise: roles for clusterin in pathogenesis, progression and therapy of cancer. Cell Death Differ 2006, 13:12-19.

30. Zhang H, Kim JK, Edwards CA, Xu Z, Taichman R, Wang CY: Clusterin inhibits apoptosis by interacting with activated Bax. Nat Cell Biol 2005, 7:909-915.

31. Steinberg J, Oyasu R, Lang S, Sintich S, Rademaker A, Lee C, Kozlowski JM, Sensibar JA: Intracellular levels of SGP-2 (Clusterin) correlate with tumor grade in prostate cancer. Clin Cancer Res 1997, 3:1707-1711.

32. Sowery RD, Hadaschik BA, So Al, Zoubeidi A, Fazli L, Hurtado-Coll A, Gleave ME: Clusterin knockdown using the antisense oligonucleotide OGX-011 re-sensitizes docetaxel-refractory prostate cancer PC-3 cells to chemotherapy. BJU Int 2008, 102:389-397.

33. Simpson LA, Burwell EA, Thompson KA, Shahnaz S, Chen AR, Loeb DM: The antiapoptotic gene A1/BFL1 is a WT1 target gene that mediates granulocytic differentiation and resistance to chemotherapy. Blood 2006, 107:4695-4702.

34. Modur V, Nagarajan R, Evers BM, Milbrandt J: FOXO proteins regulate tumor necrosis factor-related apoptosis inducing ligand expression. Implications for PTEN mutation in prostate cancer. J Biol Chem 2002, 277:47928-47937.

35. Yasuda M, Han JW, Dionne CA, Boyd JM, Chinnadurai G: BNIP3alpha: a human homolog of mitochondrial proapoptotic protein BNIP3. Cancer Res 1999, 59:533-537.
36. Degli-Esposti MA, Dougall WC, Smolak PJ, Waugh JY, Smith CA, Goodwin RG: The novel receptor TRAIL-R4 induces NF-kappaB and protects against TRAIL-mediated apoptosis, yet retains an incomplete death domain. Immunity 1997, 7:813-820.

37. Karin M, Yamamoto Y, Wang QM: The IKK NF-kappa B system: a treasure trove for drug development. Nat Rev Drug Discov 2004, 3:17-26.

38. Pu YS, Hour TC, Chuang SE, Cheng AL, Lai MK, Kuo ML: Interleukin-6 is responsible for drug resistance and anti-apoptotic effects in prostatic cancer cells. Prostate 2004, 60:120-129.

39. Venkatraman M, Anto RJ, Nair A, Varghese M, Karunagaran D: Biological and chemical inhibitors of NF-kappaB sensitize SiHa cells to cisplatininduced apoptosis. Mol Carcinog 2005, 44:51-59.

40. Hour TC, Chen J, Huang CY, Guan JY, Lu SH, Pu YS: Curcumin enhances cytotoxicity of chemotherapeutic agents in prostate cancer cells by inducing p21(WAF1/CIP1) and C/EBPbeta expressions and suppressing NF-kappaB activation. Prostate 2002, 51:211-218.

41. Li Y, Ahmed F, Ali S, Philip PA, Kucuk O, Sarkar FH: Inactivation of nuclear factor kappaB by soy isoflavone genistein contributes to increased apoptosis induced by chemotherapeutic agents in human cancer cells. Cancer Res 2005, 65:6934-6942.

doi:10.1186/1476-4598-10-126

Cite this article as: O'Neill et al: Characterisation and manipulation of docetaxel resistant prostate cancer cell lines. Molecular Cancer 2011 10:126.

\section{Submit your next manuscript to BioMed Central and take full advantage of:}

- Convenient online submission

- Thorough peer review

- No space constraints or color figure charges

- Immediate publication on acceptance

- Inclusion in PubMed, CAS, Scopus and Google Scholar

- Research which is freely available for redistribution

Submit your manuscript at www.biomedcentral.com/submit
C BioMed Central 